\title{
Effect of pulsed electric fields upon accumulation of magnesium in Saccharomyces cerevisiae
}

\author{
Urszula Pankiewicz $\cdot$ Jerzy Jamroz
}

Received: 10 February 2010/Revised: 14 June 2010/Accepted: 23 June 2010/Published online: 6 July 2010

(C) The Author(s) 2010. This article is published with open access at Springerlink.com

\begin{abstract}
Cultures of Saccharomyces cerevisiae were treated with PEF to improve accumulation of magnesium in the biomass. Under optimized conditions, that is, on 15-min exposure of the 20-h grown culture to PEF of the 2,000 V and $20-\mu$ s pulse width, accumulation of magnesium in the yeast biomass reached maximum $3.98 \mathrm{mg} / \mathrm{g} \mathrm{dm}$. It constituted $40 \%$ of the total magnesium in the medium. That accumulation significantly correlated against magnesium concentration in the medium. Neither multiple exposure of the cultures to PEF nor intermittent supplementation of the cultures with magnesium increased the magnesium accumulation. The intermittent supplementation of the cultures with magnesium could even reduce the accumulation efficiency by $30 \%$.
\end{abstract}

Keywords Magnesium · Biomass .

Saccharomyces cerevisiae . Pulsed electric fields

\section{Introduction}

Magnesium ions are essential for the growth and metabolism of yeast cells [1-3]. Magnesium ions also stabilize ribosomal nucleic acids, membrane structures and protect yeast cells against environmental stress during either fermentation or high osmotic pressure [4-6]. The high daily requirement of magnesium for the human organism results from the role of the $\mathrm{Mg}$ ions as a cofactor for the activity of over 300 enzymes

\footnotetext{
U. Pankiewicz (更) · J. Jamroz

Department of Analysis and Evaluation of Food Quality,

Faculty of Food Science and Biotechnology,

University of Life Sciences, Skromna Street 8,

20-704 Lublin, Poland

e-mail: urszula.pankiewicz@up.lublin.pl
}

[7, 8]. Magnesium in living cells is bound mostly to phospholipids, proteins and nucleotides, except a small fraction, which resides there in a free form [7, 9-11]. In recent years, there has emerged a growing concern about magnesium deficiency in humans and animals. For that reason, supplementation of the diet with magnesium became an indispensable procedure. Yeast biomass appeared to be a suitable source of deficient elements and vitamins. Thus, enriched in magnesium, such biomass could be an option for pharmacological supplementation with that element.

Organisms better tolerate and assimilate bioelements in the form of metalloproteins than as components of pharmaceuticals. In the future, foodstuffs containing either magnesium-enriched yeast or yeast preparations containing magnesium biocomplexes could become additional sources of that element $[12,13]$.

Microorganisms bioaccumulate metals in two stages. In the first step, the metal ions adhere to the surface of cell membranes followed by their binding to intramicrofibrilar structures of the cell wall by adsorption and/or complexing. Metals are usually introduced through either ion exchange, precipitation or co-crystallization. The second stage involves an active transport of the metal ions through a cytoplasmatic membrane to the cell interior [1, 14-17].

Pulsed electric fields (PEF) technology offers a nonthermal food preservation that kills most pathogenic and putrefactive microorganisms, inactivates enzymes and limits the loss of taste, color, texture, nutrients, and heat labile functional food components [18-20]. The electric field can affect the cell membranes [21], which can irreversibly be damaged [22-24], influences the transport of ions [25] and structure of enzymes [26]. In a cell subjected to PEF-induced transmembrane tension facilitates the formation of pores in the membrane and leads to an increase in its permeability [27-31]. Electroporation temporarily 
eliminates integrity of the plasmatic membrane, i.e., produces small pores that close back with a time [31-33].

The aim of this paper was to test whether PEF is a suitable technique for the magnesium enrichment of Saccharomyces cerevisiae.

\section{Materials and methods}

Culture maintenance and inoculum preparation

Saccharomyces cerevisiae $11 \mathrm{~B}_{1}$ (industrial strain) from the Yeast Plant (Lublin, Poland) was used.

Medium for agar slants and inoculum growth $(\mathrm{g} / \mathrm{L})$ : sucrose (20); $\mathrm{NH}_{4} \mathrm{Cl}$ (3.2); $\mathrm{KH}_{2} \mathrm{PO}_{4}$ (2.5); $\mathrm{Na}_{2} \mathrm{SO}_{4}$ (2.0) (POCH, Gliwice, Poland); yeast extract (YE) (5.0); agar (15) (DIFCO, Detroit, MI, USA); and unhoped wort (40.0 mL) (Lublin Breweries S.A., Lublin, Poland) had $\mathrm{pH}$ 5. Experimental medium for $S$. cerevisiae contained $\left(\mathrm{g} / \mathrm{dm}^{3}\right)$ : peptone (10) (Sigma-Aldrich CO, St. Louis, MI, USA); YE (5); glucose (10) (POCH, Gliwice, Poland) [7].

\section{Biomass cultivation}

Yeast was passaged three times for agar slants, grown for $48 \mathrm{~h}$ in a thermostat at $30{ }^{\circ} \mathrm{C}$ and finally an inoculum was prepared. Cells from a single slant were used to inoculate $150 \mathrm{~mL}$ sterile medium in an Erlenmeyer flask. Cultures were grown on a rotary shaker with water bath, at amplitude 4 and at $220 \mathrm{rpm}$ for $48 \mathrm{~h}$ at $30{ }^{\circ} \mathrm{C}$. The fermented medium was centrifuged, washed three times with sterile water, and the remaining washed biomass of cells from three Erlenmeyer flasks was diluted with sterile water to a final volume of $300 \mathrm{~mL}$. The inoculum was made of 48 -h yeast cultures with $\mathrm{OD}_{400}$ of 2.2 (Spekol 11, Carl Zeiss, Jena, Germany). Biomass inoculum with washing was $12.2 \mathrm{~g} \mathrm{dw} / \mathrm{L}$. The inoculum prepared in this manner was used for the inoculation of submerged grown in 500-mL Erlenmeyer flasks, each containing $100 \mathrm{~mL}$ medium inoculated with $10 \mathrm{~mL}$ inoculum. The culturing conditions were identical to those applied for the inoculum preparation. After $42 \mathrm{~h}$ culturing, the mycelium was centrifuged, washed several times with distilled water, and then lyophilized in a Labconco freeze dryer (Model 64132, Kansas City, MO, USA).

PEF treatment and enrichment with magnesium

S. cerevisiae cultures grown in flasks were agitated for $20 \mathrm{~h}$ then treated with PEF for 15 min (electroporator ECM 830, BTX Harvard Apparatus, USA) at the field frequency of $1 \mathrm{~Hz}$ and $20-\mu$ s pulse width. Simultaneously, voltage was optimized on the field exposition of 50, 100, 150, 200, 250, $500,1,000,1,500,2,000$ and $2,500 \mathrm{~V}$.
Optimization of the PEF exposition time for $20 \mathrm{~h}$ was performed culturing the yeast for 5, 10, 15 and $20 \mathrm{~min}$, at optimum voltage of $2,000 \mathrm{~V}$. The PEF pulse width at 10 , $20,50,75,100,125$ and $150 \mu$ s was selected at $2,000 \mathrm{~V}$ on the 15-min exposition.

Optimization of the time interval after which yeast cells were 15 min treated with PEF was performed after 8, 12, 16,20 and $24 \mathrm{~h}$ culturing at $2,000 \mathrm{~V}$ and $20 \mu$ s pulse width. Concentration of magnesium in the nutrient broth was estimated for PEF-treated cells cultured at given field parameters and time of culturing. Subsequent culturing of $S$. cerevisiae was carried out in the medium containing 10 , 100, 200, 400, 500, 750 and 1,000 $\mu \mathrm{g} / \mathrm{mL}$ magnesium.

At optimum PEF parameters and $100 \mu \mathrm{g} / \mathrm{mL}$ magnesium concentration, the medium was additionally enriched with subsequent $25 \mu \mathrm{g} / \mathrm{mL}$ doses of magnesium after 8,12 , 16 and $20 \mathrm{~h}$ culturing. Subsequent culturing was performed under optimized conditions, and these cultures were PEF treated several times after $8,12,16$ and $20 \mathrm{~h}$. The results allowed to check the role of enrichment with magnesium and number of expositions to PEF upon the magnesium accumulation in the yeast cells. Samples not treated with PEF and without magnesium in the medium (K1) or with $100 \mu \mathrm{g} \mathrm{Mg} / \mathrm{mL}$ (K2) served as controls.

\section{Determination of the magnesium concentration}

Mineralization of yeast for the determination of the magnesium concentration using the method of flame atomic absorption spectrophotometry (FAAS, Solaar 939, Unicam) was conducted as follows: $250 \mathrm{mg}$ samples of lyophilized magnesium-enriched yeast were weighed into glass thimbles, $3 \mathrm{ml} \mathrm{HNO}_{3}-\mathrm{HClO}_{4}$ (5:1) was added, the mixtures were left overnight then heated in a heating block at $250{ }^{\circ} \mathrm{C}$ for $20 \mathrm{~h}$. After cooling, solutions were transferred to $50 \mathrm{~mL}$ measuring flasks and topped up with deionized water.

Determination of the yeast cell viability

Cell viability was determined in the Thoma chamber, dyeing necrotic yeast cells with the $0.01 \%$ methylene blue solution. The percentage of necrotic cells was the mean of 16 fields calculated according to the formula: \% necrotic cells $=$ (number of necrotic cells/sum of necrotic and living cells) $\times 100 \%$.

Determination of the crop of yeast biomass

Biomass was estimated from optical density at $400 \mathrm{~nm}$. Dry mass was calculated by referring a standard curve of cell mass versus absorbance. The fermented medium from culturing $(2 \mathrm{~mL})$ was centrifuged $(3,000 \mathrm{rpm})$, and 
supernatant was discarded; cells were rinsed with deionized water and brought to the original volume of $2 \mathrm{~mL}$. Nephelometric measurements were run against pure water in 2-mm measurement cell. Amount of dry residue was calculated using equation for the standard curve: $A_{\mathrm{p}}=0.4476 \mathrm{c}$, where $A_{\mathrm{p}}$ and c were apparent absorbance and concentration $(\mathrm{mg} / \mathrm{mL})$, respectively.

Data analysis

Significant differences between particular groups were found involving the Student's t-test applied to compare independent samples in pairs, and variance analysis (ANOVA) was used for more than two groups. Statistical processing of results was performed using Statistica 6.0 software.

\section{Results and discussion}

Experiments showed that low voltage in the range of 50-500 $\mathrm{V}$ did not influence the magnesium accumulation in the yeast cells maintaining it on the level of $1.9 \mathrm{mg} / \mathrm{g} \mathrm{dm}$, which is not significantly different to control sample K2 (Fig. 1). In the control culture K1, magnesium accumulation was $1.2 \mathrm{mg} / \mathrm{g} \mathrm{dm}$. Statistically essential changes in accumulation appeared just when voltage above $500 \mathrm{~V}$ was applied and that of 2,000 $\mathrm{V}$ provided maximum accumulation reaching $3.98 \mathrm{mg} / \mathrm{g} \mathrm{dm}$, that is, twice as much as in the $\mathrm{K} 2$ sample. The voltage exceeding 2,000 V reduced the magnesium accumulation. Voltage applied had an essential influence on the cell vitality (Fig. 2). An elevation of voltage in the range from 500 to $2,500 \mathrm{~V}$ resulted in a gradual increase in the count of necrotic cells. At optimum 2,000 V, there were $9.5 \%$ necrotic cells in the culture, and at 2,500 V, the count of necrotic cells was by three times as high as at $500 \mathrm{~V}$.
Prolonged PEF treatment increased the magnesium content in the cell biomass (Fig. 3). The 15-min exposure provided the highest accumulation of magnesium reaching $4 \mathrm{mg} / \mathrm{g} \mathrm{dm}$ i.e., by 23 and $4 \%$ higher concentration in respect to 5- and 20-min exposure, respectively.

The pulse width also appeared to be an essential factor. The $20-\mu$ s pulse width provided superior magnesium accumulation of $4 \mathrm{mg} / \mathrm{g} \mathrm{dm}$ (Fig. 4). This value was by $28 \%$ higher then that acquired with the $10-\mu$ s pulse width. Pulse width elevated above $20 \mu$ s caused essential decrease in the magnesium accumulation. The pulse width affected also the cell vitality (Fig. 5). The 10- $\mu$ s pulse width did not practically affect their vitality, which was the same as in the control K2 sample not treated with PEF. At optimum magnesium concentration in yeast $(4 \mathrm{mg} / \mathrm{g} \mathrm{dm})$ and the $20-\mu$ s pulse width, the culture contained $9.5 \%$ necrotic cells. Increase in the pulse width to $50 \mu$ s doubled amount of necrotic cells. Further increase in the pulse width up to $125 \mu$ s had no statistically significant effect on the cell vitality; however, at the $150-\mu$ s pulse width, the culture contained already $35 \%$ necrotic cells. Hülsheger et al. [27] reported over $99.99 \%$ inactivation of microorganisms exposed to peak electric fields of $20 \mathrm{kV} / \mathrm{cm}$ and pulses of several milliseconds.

Control culture K1 without magnesium supplementation and PEF treatment accumulated magnesium on the level of $1 \mathrm{mg} / \mathrm{g} \mathrm{dm}$. The supplementation with magnesium without the PEF treatment (control K2) provided an increase in accumulated magnesium up to $1.86 \mathrm{mg} / \mathrm{g} \mathrm{dm}$.

Duration of the culturing after the PEF treatment had no effect upon the magnesium accumulation (Fig. 6). Under applied culturing conditions, the maximum magnesium concentration in the cells reached $4 \mathrm{mg} / \mathrm{g} \mathrm{dm}$ after $20 \mathrm{~h}$, which was by 34 and $23 \%$ higher than that after 8 and $24 \mathrm{~h}$ culturing, respectively. Results presented in Figs. 1, 2, 3, 4, 5,6 reveal that the least and most biomass with washing (7.8 and $9.7 \mathrm{~g} \mathrm{dw} / \mathrm{L}$, respectively) formed at $50-\mu \mathrm{s}$ pulse
Fig. 1 Effect of voltage PEF treatment upon magnesium accumulation in S. cerevisiae. Means with the same letters are not significantly different $(P \geq 0.05 ; n=6)$

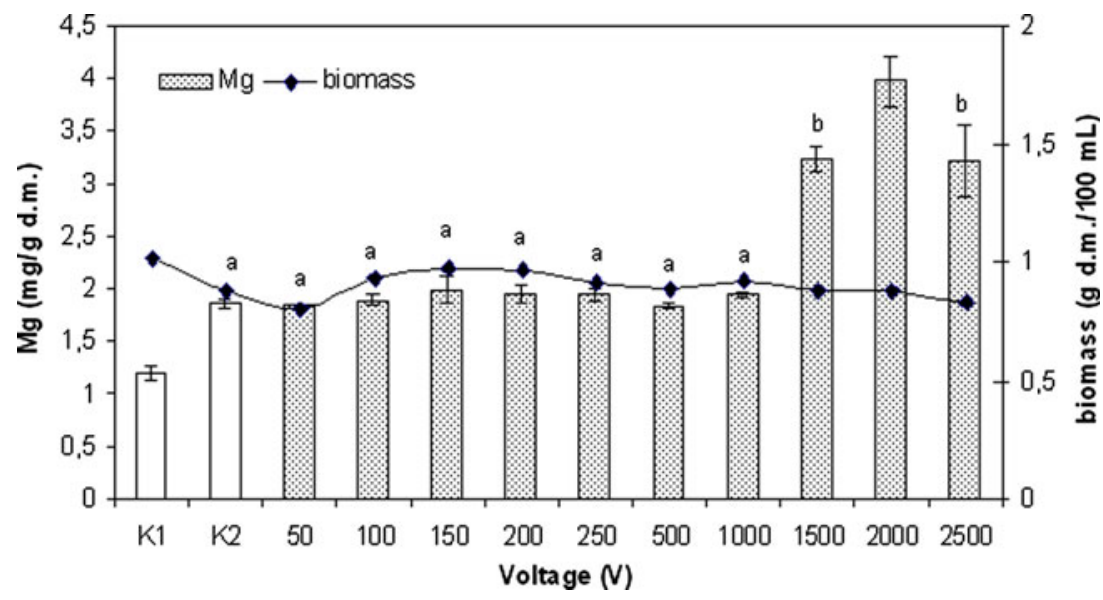




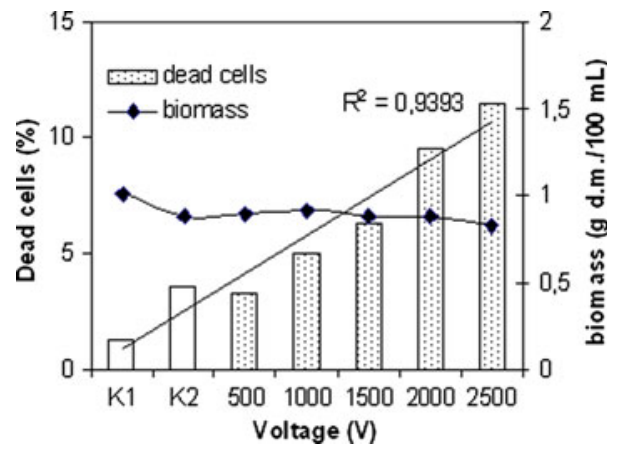

Fig. 2 Effect of the PEF voltage upon the vitality of $S$. cerevisiae cells

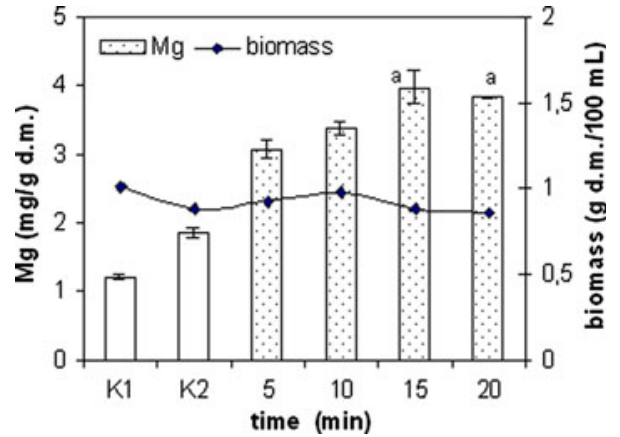

Fig. 3 Accumulation of magnesium in the cell biomass dependent on the time of exposure to PEF. Means with the same letters are not significantly different $(P \geq 0.05 ; n=6)$

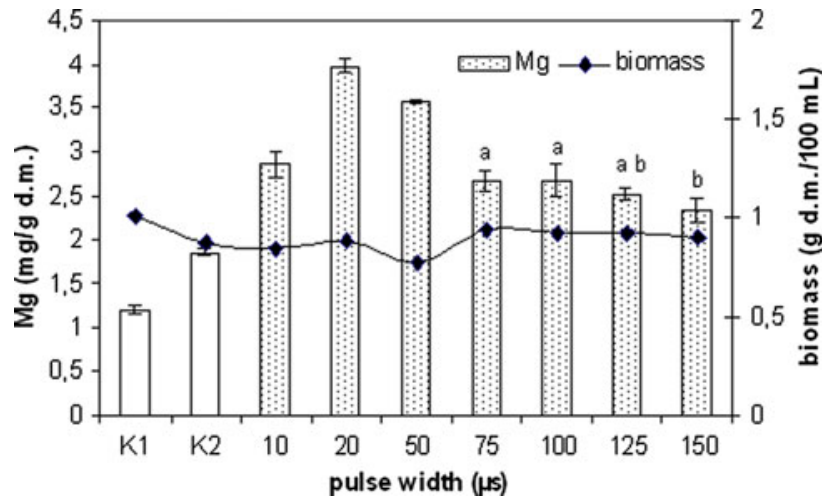

Fig. 4 Effect of the PEF pulse width upon accumulation of magnesium in $S$. cerevisiae. Means with the same letters are not significantly different $(P \geq 0.05 ; n=6)$

width (Fig. 4), and after 10-min exposure PEF (Fig. 3), respectively.

Accumulation of magnesium in the cells increased with the increase of the magnesium concentration in the nutrient medium and that increase was not proportional (Fig. 7). At the optimum $100 \mathrm{mg} / \mathrm{mL}$ magnesium concentration in the medium, the accumulation was doubled when compared to that in the control $\mathrm{K} 2$ sample. It reached $4 \mathrm{mg} \mathrm{Mg} / \mathrm{g} \mathrm{dm}$, that is, about $40 \%$ additional magnesium was accumulated.

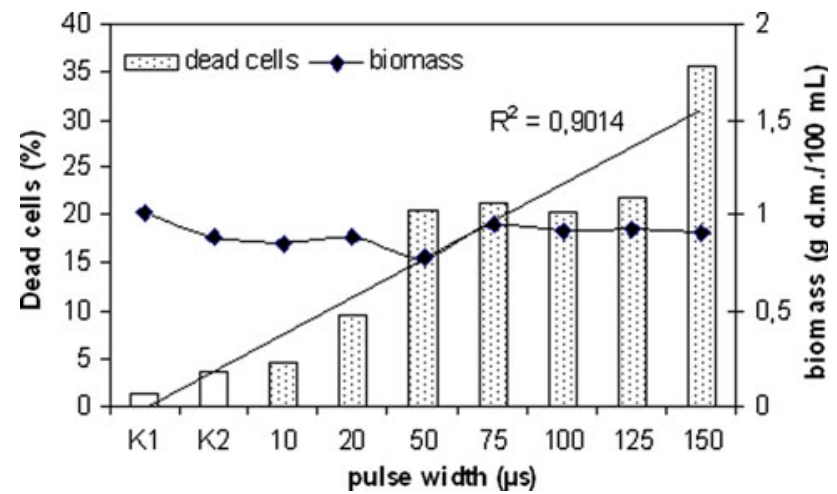

Fig. 5 Effect of the PEF pulse width upon the vitality of the S. cerevisiae cells

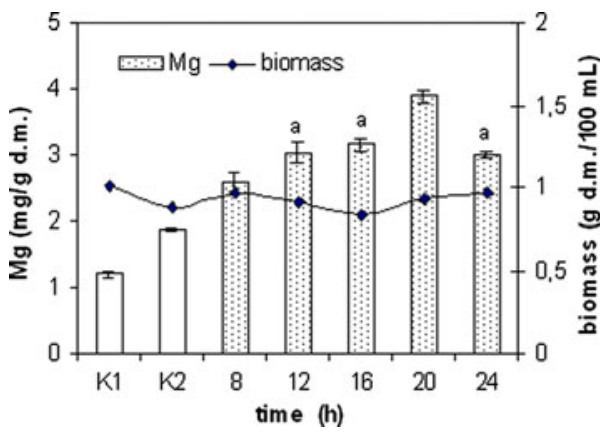

Fig. 6 Effect of the after PEF treatment culturing duration upon the magnesium concentration in $S$. cerevisiae cells. Means with the same letters are not significantly different $(P \geq 0.05 ; n=6)$

At $1,000 \mu \mathrm{g} \mathrm{Mg} / \mathrm{mL}$ medium, cells accumulated only $7.16 \mathrm{mg} / \mathrm{g} \mathrm{dm}$ magnesium i.e., only $7.16 \%$ supplemented magnesium. Increase in the magnesium concentration in the medium from 200 to $750 \mu \mathrm{g} \mathrm{Mg} / \mathrm{mL}$ resulted in the $26 \%$ increase in the accumulation of that element. However, such increase in the level of magnesium in the medium without PEF treatment had only a slight effect upon the accumulation. It was 1.4 and $1.98 \mathrm{mg} / \mathrm{g} \mathrm{dm}$ for the 10 and $1,000 \mu \mathrm{g} \mathrm{Mg} / \mathrm{mL}$ medium, respectively. Data presented in Fig. 7 show that the lowest biomass with washing was available at the 10 and $1,000 \mu \mathrm{g} / \mathrm{ml}$, magnesium concentration in the medium, whereas the concentration of $100 \mu \mathrm{g} / \mathrm{ml}$, provided 7.4 and $9.3 \mathrm{~g} \mathrm{dw} / \mathrm{L}$ biomass, respectively. In the cultures enriched with $\mathrm{Mg} \mathrm{Cl}_{2} \cdot 6 \mathrm{H}_{2} \mathrm{O}\left(1.25 \mathrm{~g} \mathrm{Mg}^{2+} / \mathrm{L}\right)$, after $48 \mathrm{~h}$ Błażejak et al. [34] collected $5.77 \mathrm{~g} \mathrm{dw} / \mathrm{L}$ biomass with washing.

In $48 \mathrm{~h}$ culturing $S$. cerevisiae $0.5 \mathrm{~g} \mathrm{Mg}^{+2} / \mathrm{L}$ added, Duszkiewicz and Gniewosz [35] noted $3.13 \mathrm{mg} \mathrm{Mg} / \mathrm{g} \mathrm{dm}$ in the rinsed biomass. That accumulation was by $30 \%$ higher than in the control culture, which was not supplemented with magnesium. Varying concentration of supplemented magnesium independently of the source and the dose did not affect magnesium accumulation. Effect upon accumulation of that element. At the supplementation of 


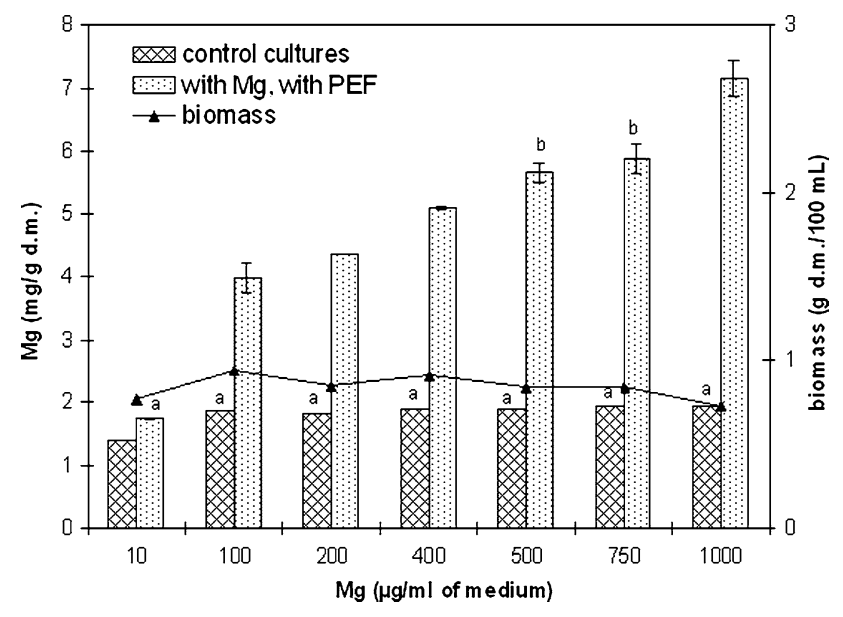

Fig. 7 Magnesium accumulation in $S$. cerevisiae depending on its supplementation level in the broth. Control cultures: no PEF (K1), supplemented with $\mathrm{Mg}(\mathrm{K} 2)$. Means with the same letters are not significantly different $(P \geq 0.05 ; n=6)$

0.25 and $1.25 \mathrm{~g} \mathrm{Mg}^{+2} / \mathrm{L}$, the authors found 2.92 and $3.2 \mathrm{mg} \mathrm{Mg} / \mathrm{g} \mathrm{dm}$ accumulated magnesium, respectively. Amount of accumulated magnesium constituted barely $10 \%$ of that supplemented.

Walker and Maynard [8] reached maximum accumulation of magnesium, $450 \mu \mathrm{M}$, after $40 \mathrm{~h}$ culturing in the medium containing $347 \mu \mathrm{M}$ magnesium. Higher concentration of magnesium, $496 \mu \mathrm{M}$, provided $300 \mu \mathrm{M}$ of accumulated element after $58 \mathrm{~h}$ culturing. After $17 \mathrm{~h}$ culturing in the broth with $30 \mathrm{mM}$ magnesium, Blackwell et al. [7] found magnesium accumulation on the level of 4,000 nmol $\left(10^{9} \text { cells }\right)^{-1}$.

This study revealed that multiple exposition of the yeast culture to PEF did not increase the accumulation in the yeast cells. Four subsequent 15 -min exposures to PEF of 8 , 12,16 and $20 \mathrm{~h}$ lasting culturing provided accumulation of $4.18 \pm 0.33 \mathrm{mg} / \mathrm{g} \mathrm{dm}$ magnesium, which was only $5 \%$ higher than that after single PEF treatment $(3.98 \mathrm{mg} / \mathrm{g} \mathrm{dm})$. Supplementation of total magnesium in four subsequent doses to cultures lasting 8,12, 16 and $20 \mathrm{~h}$ had no effect upon the accumulation. A portion wise supplementation provided accumulation of $3.05 \pm 0.11 \mathrm{mg} / \mathrm{g} \mathrm{dm}$ of magnesium in the cells. Thus, it was by $30 \%$ lower than that after the single addition of magnesium at the beginning of the culturing.

\section{Conclusions}

1. Optimized all voltage $(2,000 \mathrm{~V})$, exposure time (15 min), the pulse width $(20 \mu \mathrm{s})$ and the point of treatment in course of the growth of cultures $(20 \mathrm{~h})$ provide the highest level of the magnesium accumulation in Saccharomyces cerevisiae.
2. At $100 \mathrm{mg} / \mathrm{mL}$ magnesium concentration in the medium, the $40 \%$ accumulation of that element was achieved.

3. That accumulation significantly correlated against magnesium concentration in the medium.

Open Access This article is distributed under the terms of the Creative Commons Attribution Noncommercial License which permits any noncommercial use, distribution, and reproduction in any medium, provided the original author(s) and source are credited.

\section{References}

1. Walker GM (1994) The roles of magnesium in biotechnology. Crit Rev Biotechnol 14:311-354

2. Li LG, Tutone AF, Drummond RSM, Gardner RC, Luan S (2001) A novel family of magnesium transport genes in arabidopsis. Plant Cell 13:2761-2775

3. Gardner RC (2003) Genes for magnesium transport. Curr Opin Plant Biol 6:263-267

4. D'Amore T, Panchal CJ, Russell I, Stewart GG (1988) Osmotic pressure effects and intracellular accumulation of ethanol in yeast during fermentation. J Ind Microbiol 2:365-372

5. Blackwell KJ, Tobin IM, Avery SV (1997) Manganese uptake and toxicity in magnesium- supplemented and unsupplemented Saccharomyces cerevisiae. Appl Microbiol Biotechnol 47:180-184

6. Walker GM, Maynard AI (1997) Accumulation of magnesium ions during fermentative metabolism in Saccharomyces cerevisiae. J Ind Microbiol Biot 18:1-3

7. Romani AMP, Maguire ME (2002) Hormonal regulation of $\mathrm{Mg} 2+$ transport and homeostasis in eukaryotic cells. Biometals $15: 271-283$

8. Shaul O (2002) Magnesium transport and function in plants: the tip of the iceberg. Biometals 15:309-323

9. Bui DM, Gregan J, Jarosch E, Ragnini A, Schweyen RJ (1999) The bacterial magnesium transporter CorA can functionally substitute for its putative homologue Mrs2p in the yeast inner mitochondria membrane. J Biol Chem 274:20438-20443

10. Graschopf A, Stadler JA, Hoellerer MK, Eder S, Sieghardt M, Kohlwein SD, Schweyen RJ (2001) The yeast plasma membrane protein A1r1 controls $\mathrm{Mg} 2+$ homeostasis and is subject to $\mathrm{Mg} 2+-$ dependent control of its synthesis and degradation. J Biol Chem 276:16216-16222

11. da Costa BMT, Cornish K, Keasling JD (2007) Manipulation of intracellular magnesium levels in Saccharomyces cerevisiae with deletion of magnesium transporters. Appl Microbiol Biotechnol 77:411-425

12. Błażejak S, Duszkiewicz-Reinhard W, Gniewosz M, Mazurkiewicz B (2004) Distribution of magnesium in the Candida utilis ATCC 9950 yeast cells enriched in that element (in Polish). Acta Sci Pol Technologia Alimentaria 3:95-110

13. Gniewosz M, Błażejak S, Roman J, Duszkiewicz-Reinhard W (2006) A study on Saccharomyces cerevisiae and Candida utilis cell Wall capacity for binding magnesium. Eur Food Res Technol 224:49-54

14. Brady D, Duncan JR (1994) Bioaccumulation of metal cations by Saccharomyces cerevisiae. Appl Microbiol Biotechnol 41:149-154

15. Blackwell KJ, Singelton I, Tobin JM (1995) Metal cation uptake by yeast: a review. Appl Microbiol Biotechnol 43:579-584

16. Tuszyński T, Pasternakiewicz A (2000) Bioaccumulation of metal ions by yeast cells of Saccharomyces cerevisiae. Pol J Food Nutr Sci 4:31-39 
17. Liu GJ, Martin DK, Gardner RC, Ryan PR (2002) Large $\mathrm{Mg}^{2+}$ dependent currents are associated with the increased expression of ALR1 in Saccharomyces cerevisiae. Microbiol Lett 213:231237

18. Torregrosa F, Esteve MD, Frigola A, Cortes C (2006) Ascorbic acid stability during refrigerated storage of orange-carrot juice treated by high pulsed electric field and comparison with pasteurized juice. J Food Eng 73:339-345

19. Marselles-Fontanet AR, Martin-Belloso O (2007) Optimization and validation of PEF processing conditions to inactivate oxidative enzymes of grape juice. J Food Eng 83:452-462

20. Sampedro F, Rivas A, Rodrigo D, Martinez A, Rodrigo M (2007) Pulsed electric fields inactivation of Lactobacillus plantarum in an orange juice-milk based beverage: effect of process parameters. J Food Eng 80:931-938

21. Barsotti L, Cheftel JC (1999) Food processing by pulsed electric fields. II. Biological aspects. Food Rev Inter 5:181-213

22. Zimmermann U (1986) Electrical breakdown, electropermeabilization and electrofusion. Rev Physiol Biochem Pharmacol 105:175-256

23. Pothakamury UR, Barbosa-Canovas GV, Swanson BG, Spence KD (1997) Ultrastructural changes in Staphylococcus aureus treated with pulsed electric fields. Food Sci Technol Int 3:113121

24. Calderon-Miranda ML, Barbosa-Canovas GV, Swanson BG (1999) Transmission electron microscopy of Listeria innocua treated by pulsed electric fields and nisin in skimmed milk. Inter J Food Microbiol 51:31-39

25. Kim H, Ye J, Li Y (2001) Inactivation of Listeria monocytogenes in chilling brine using a flow through electrochemical treatment. Institute of Food Technologists, annual meeting. Paper 59H-22

26. Fernandez-Diaz MD, Barsotti L, Dumay E, Cheftel JC (2000) Effects of pulsed electric fields on ovalbumin solutions and dialyzed egg white. J Agr Food Chem 48:2332-2339
27. Hülsheger H, Potel J, Niemann EG (1983) Electric field effects on bacteria and yeast cells. Radiat Environ Biophys 22:149-162

28. Zhang Q, Chang FJ, Barbosa-Canovas GV, Swanson BG (1994) Inactivation of microorganisms in a semisolid model food using high voltage pulsed electric fields. LWT 27:538-543

29. Evrendilek GA, Zhang HQ, Richter ER (1999) Inactivation of Escherichia coli $\mathrm{O} 157: \mathrm{H} 7$ and Escherichia coli 8739 in apple juice by pulsed electric field. J Food Protect 62:793-796

30. Wouters PC, Dutreux N, Smelt JPP, Lelieveld HM (1999) Effects of pulsed electric fields on inactivation kinetics of Listeria innocua. Appl Environ Microbiol 62:5364-5371

31. Aronsson K, Rönner U, Borch E (2005) Inactivation of Escherichia coli, Listeria innocua and Saccharomyces cerevisiae in relation to membrane permeabilization and subsequent leakage of intracellular compounds due to pulsed electric field processing. Int J Food Microbiol 99:19-32

32. Barbosa-Canovas GV, Gongora-Nieto MM, Pothakamury UR, Swanson BG (1999) Preservation of foods with pulsed electric field. Academic Press, San Diego, CA

33. Aronsson K, Rönner U (2001) Influence of $\mathrm{pH}$, water activity and temperature on the inactivation of Escherichia coli and Saccharomyces cerevisiae by pulsed electric fields. Innov Food Sci Emerg Technol 2:105-112

34. Błażejak S, Duszkiewicz-Reinhard W, Gniewosz M, Rostkowska-Demner E, Domurad E (2002) The study of Saccharomyces cerevisiae brewery yeast strain capacity of binding with magnesium in dynamic conditions. EJPAU, Food Sci Technol $5: 1-8$

35. Duszkiewicz-Reinhard W, Gniewosz M, Błażejak S, Bańkowski A (2002) Study on the ability of Saccharomyces cerevisiae to bind magnesium in the stationary cultures (in Polish). Acta Sci Pol Technologia Alimentaria 1:17-26 